\title{
Not-For-Profit Organizations And For-Profit Businesses: Perceptions And Reality
}

Samuel H. Tolbert, Lander University, USA

Gail D. Moore, Lander University, USA

Carol P. Wood, Lander University, USA

\begin{abstract}
Not-for-profit organizations represent an important portion of the gross domestic product of the United States; yet there are many misconceptions in the business world regarding not-for-profits. This paper analyzes two surveys -- one of business persons and the other of seniors in an undergraduate business program - to determine the extent of the suspected misconceptions. Then the paper presents factual support to correct typical misconceptions regarding how not-for-profit organizations operate.
\end{abstract}

Keywords: Not-for-profit organizations, 501(c)(3), tax-exempt status, eleemosynary

\section{INTRODUCTION}

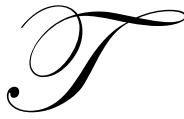

he authors collectively have over eighty years of full-time professional business experience and maintain private consulting practices in addition to their full-time faculty appointments. The authors concluded there is substantial anecdotal evidence of a general misunderstanding of the Not-for-Profit sector in the United States. A literature search revealed very little published research on the subject or papers that address the similarities and differences between For-Profit Businesses (FP's) and Not-for-Profit Organizations (NFP's).

\section{Not-for-Profit Organizations - Background}

Not for Profit organizations is a sector of the U.S. economy that continues to show marked growth. Between the years 2002 and 2004 employment for NFP's grew by 5\% when total private employment grew less than 1\%. Also, the number of NFP's has grown by $36 \%$ in the last 10 years. [8] This sector includes more than half the Nation's hospitals and higher education institutions, a significant number of retirement and nursing homes and most family service agencies, symphonies, homeless shelters, soup kitchens, community development agencies, and hospices. [7]

In a recent speech by Sarah Hall Ingram, Commissioner of the Tax Exempt and Government Entities Division of the Internal Revenue Service, she noted the following:

1. In 2008 the number of IRS approved tax exempt entities was in excess of 1.9 million.

2. As of 2005, charities that were required to file returns with the IRS reported assets in excess of $\$ 2.2$ trillion and private foundations reported an additional $\$ 546$ billion in assets. [4]

From an employment standpoint NFP's account for over $8 \%$ of total employment, FP's account for $75 \%$ and the remaining $16 \%$ of employment is in the public sector. As an employment sector, NFP employment exceeds that of Agriculture (3.25\%), Wholesale Trade (3.5\%), Transportation (4.2\%) and Finance and Insurance (5.8\%). In addition, NFP employment is almost as large as the durable goods manufacturing sector (9.5\%). [7] 
There are four general categories of NFP's:

1. Voluntary health and welfare organizations - Examples: United Way, American Cancer Society, and Boy Scouts of America

2. Health Care Organizations

3. Colleges and Universities

4. Other Not For Profit Organizations

- Civic Organizations

- Cultural institutions and organizations

- Private schools

- Religious organizations [6]

The Financial Accounting Standards Board in the Statement on Financial Accounting Concepts No. 4 noted the three major characteristics of Not for Profit organizations that distinguish them from For Profit businesses are:

1. A significant amount of NFP resources are received from sources that do not expect repayment or economic benefits equivalent to the resources provided.

2. The organizations are operated for purposes other than generating a profit in exchange for goods or services.

3. There are no defined ownership interests in the organizations "that can be sold, transferred, redeemed, or that convey entitlement to a share of a residual distribution" if the organization is liquidated.[2]

Similarly, the IRS definition of a NFP that is exempt from federal income tax includes provisions that a NFP may not have earnings that benefit a private shareholder or individual, may not operate for the benefit of private interests, and must not operate for the primary purpose of conducting a trade or business unrelated to its exempt purpose. [5]

\section{Not-for-Profit Organizations - Legal Basis}

To create a NFP corporation, an attorney files articles of incorporation for a non profit corporation with the Secretary of State of the state in which the company will do business. Along with stating the standard information such as name, address and registered agent of the corporation, this document outlines that the corporation chooses to be non-profit and also whether the corporation will have members or will not have members. The incorporators must choose whether the NFP will operate as a public benefit corporation, a religious organization, or a mutual benefit corporation. A public benefit corporation is an organization that is incorporated to serve the public examples are hospitals or university foundations, or public transportation authorities. Religious organizations are churches or other religious groups. Mutual benefit corporations are entities that are organized to benefit their members, such as a booster club or fraternal organization.

Once organized, not for profit businesses possess the ability to carry out their business purpose, like their for-profit counterparts. Activities a NFP can engage in without limitations include the power to sue and be sued, the power to purchase, sell, or lease real estate, the power to make contracts, to lend or borrow money, the power to be a promoter, manager or partner of any partnership, joint venture or trust, the power to impose dues and set qualifications for members, and the general powers to carry on a business and to take any actions necessary to further the activities and affairs of the company.

\section{Not-for-Profit Organizations - Tax Issue}

After the incorporators determine what type of not-for-profit category suits the company's structure and decide if the company is one that will have members, a determination of tax-exempt status should be made. In order to be deemed tax-exempt, a NFP must apply to the Internal Revenue Service. NFP companies apply by completing either Form 1023, Application for Recognition of Exemption Under Section 501(c) (3) of the Internal Revenue Code, or Form 1024, Application for Recognition of Exemption Under Section 501(a), depending on the NFP's activities. Companies whose activities actually fall into the definition of code section 501(c) (3) use Form 1023. Entities 
whose activities fall into any other section of 501 or 503 of the I.R.C. use Form 1024. These complicated forms should not be entered into without professional assistance. A misstep on the application can cause a NFP to be denied its tax-exempt status.

Table 1

\begin{tabular}{|l|l|}
\hline Code Section & \multicolumn{1}{|c|}{ Activity } \\
\hline $501(\mathrm{c})(2)$ & Title holding corporations \\
\hline $501(\mathrm{c})(3)$ & $\begin{array}{l}\text { Corporations, and any community chest, fund, or foundation, organized and operated exclusively for } \\
\text { religious, charitable, scientific, testing for public safety, literary, or educational purposes, or to foster } \\
\text { national or international amateur sports competition, or for the prevention of cruelty to children or animals }\end{array}$ \\
\hline $501(\mathrm{c})(4)$ & Civic leagues, social welfare organizations \\
\hline $501(\mathrm{c})(5)$ & Labor, agricultural or horticultural organizations \\
\hline $501(\mathrm{c})(6)$ & Business leagues, chambers of commerce \\
\hline $501(\mathrm{c})(7)$ & Social Clubs \\
\hline $501(\mathrm{c})(8)$ & Fraternal beneficiary societies \\
\hline $501(\mathrm{c})(9)$ & Voluntary employees' beneficiary associations \\
\hline $501(\mathrm{c})(10)$ & Domestic fraternal societies, orders, etc. not providing life, sick, accident or other benefits \\
\hline $501(\mathrm{c})(12)$ & $\begin{array}{l}\text { Benevolent life insurance associations, mutual ditch or irrigation companies, mutual or cooperative } \\
\text { telephone companies, or like organizations }\end{array}$ \\
\hline $501(\mathrm{c})(13)$ & Cemeteries, crematoria, and like corporations \\
\hline $501(\mathrm{c})(15)$ & Mutual insurance companies or associations, other than life or marine \\
\hline $501(\mathrm{c})(17)$ & Trusts providing for the payment of supplemental unemployment compensation benefits \\
\hline $501(\mathrm{c})(19)$ & $\begin{array}{l}\text { A post, organization, auxiliary unit, etc., of past or present members of the Armed Forces of the United } \\
\text { States }\end{array}$ \\
\hline $501(\mathrm{c})(25)$ & Title holding corporations or trusts \\
\hline $501(\mathrm{e})$ & Cooperative hospital service organization \\
\hline $501(\mathrm{f})$ & Cooperative service organization of operating educational \\
\hline $501(\mathrm{n})$ & Charitable risk pool \\
\hline
\end{tabular}

Completed applications are sent to the IRS along with copies of the NFP's articles of incorporation, bylaws, schedules, and four years of financial information. The IRS reviews this information and determines whether tax-exempt status should be granted and under which code section the NFP's tax-exempt status falls. Although people think of tax-exempt groups as holding the 501(c) (3) designation, the IRS actually provides a myriad of code sections under which a company may qualify as tax-exempt.

Once the IRS approves a company's application for tax-exempt status, the company will receive a letter noting the status. A NFP's tax-exempt status is recognized at both the federal and state level.

\section{METHODOLOGY}

In order to measure the general perceptions of NFP's, the authors created a survey with ten true/false questions that addressed what they believed to be the major misconceptions regarding the differences between FP businesses and NFP organizations. Business students and business professionals completed this survey to determine the extent of misconceptions within and between each group. The survey included the following true/false questions:

1. Not-for-profit organizations are not considered businesses.

2. Not-for-profit organizations do not pay taxes.

3. Not-for-profit organizations cannot make a profit.

4. Not-for-profit organizations compensate managers less than for-profit businesses.

5. Not-for-profit organizations cannot do joint ventures with for-profits businesses.

6. Not-for-profit organizations are not permitted to compete with for-profits businesses.

7. Not-for-profit organizations are expected to only break-even.

8. Not-for-profit organizations and for-profit businesses can sell stock to raise capital. 
9. Not-for-profit organizations, like for-profit businesses, can pay dividends to its owners.

10. Not-for-profit organizations and for-profit businesses can accept donations and the amount is taxdeductable by the donor to the extent the donation exceeds the value of goods or services received.

Over a two-year period the survey was administered to students completing their last semester of business study at Lander University in Greenwood, South Carolina, where the authors have full-time faculty appointments. The University's business administration program is undergraduate-only, AACSB accredited, and offers four areas of emphasis: Accounting, Economics/Finance, Health Care Management, and Management/Marketing. Lander University has a student body of approximately 2,750 and graduates approximately 100 business administration majors each year. The survey captured the answers to the ten true/false questions and demographic information, particularly the student's area of emphasis. This was judged to be important since the students in Health Care Management (HMCT) have more exposure to NFP's than students in the other three areas of emphasis and the authors wanted to see if there was any difference in the levels of understanding between students in the emphasis areas. The student survey was conducted using a paper form and the data was entered into an Excel spreadsheet for analysis.

In the spring of 2009, the questionnaire was submitted to local business professionals using an online survey system. The Greenwood Area Chamber of Commerce emailed the online survey link to its distribution list which included approximately 1,300 addresses. The survey was completed by 181 chamber member and the data was downloaded into Excel for analysis.

\section{ANALYSIS}

A total of 146 senior business students completed the survey. The distribution by emphasis is shown on table 2. So differences in level of understanding could be compared, the students were categorized into two groups: HCMT and not-HCMT. The authors expected the not-HCMT students would have a higher level of misconception regarding NFP's.

Table 2

\begin{tabular}{|c|r|l|}
\hline Responses & & \multicolumn{2}{|c|}{ Analyzed as } \\
\hline Accounting & 29 & Not HCMT \\
\hline Econ/Finance & 14 & Not HCMT \\
\hline Health Care Mgt & 37 & HCMT \\
\hline Mgt/Mrktg & 66 & Not HCMT \\
\hline Total & 146 & \\
\hline
\end{tabular}

In a similar fashion, the business professionals were grouped into those who worked in FP businesses and those who worked in the NFP sector. The distribution of the 181 responses is shown in table 3.

Table 3

\begin{tabular}{|c|r|l|}
\hline Responses & & Analyzed as \\
\hline Educational Institution & 12 & Not-for-profit Business \\
\hline For-profit Business & 118 & For-profit Business \\
\hline Government Agency & 8 & Not-for-profit Business \\
\hline Not-for-profit Business & 40 & Not-for-profit Business \\
\hline Other / Blank & 3 & Excluded from analysis \\
\hline Total & 181 & \\
\hline
\end{tabular}

Three individuals did not indicate the type of business in which they were employed (FP versus NFP) and were excluded from the analysis. 
For each of the ten questions, a comparison of significant difference was made between the students and business professionals and between the two groups within each. The Z-Test for the difference in two proportions was used to determine if the differences were significantly different. Significance was measured at $95 \%$ and $90 \%$ confidence levels. Due to the lower sample size within the groups of each survey, the lower confidence level was applied.

The remainder of this paper presents the conclusions of the comparisons and the factual information that dispels the misconceptions represented in the true/false questions.

\section{FINDINGS}

\section{Not-for-profit organizations are not considered businesses.}

Overall, $15 \%$ of the respondents believe that NFP's are not considered businesses. The perception was significantly higher among business professional (22\%) than among business students (8\%). Within each survey group there were no significant differences in responses between business professionals working in FP's and NFP's and students studying HCMT and those not. Table 4 presents the tabulation of the responses and the z-Test for this question.

Table 4

\begin{tabular}{|l|r|r|r|c|c|c|}
\hline \multicolumn{1}{|c|}{ Respondent } & $\mathrm{N}=$ & True & Percent & z-value & at 95\% & at 90\% \\
\hline Professional-Total & 178 & 39 & $22 \%$ & \multirow{2}{*}{3.384} & \multirow{2}{*}{ Yes } & Yes \\
\hline Student-Total & 145 & 11 & $8 \%$ & & \multirow{2}{*}{ No } & \multirow{2}{*}{ No } \\
\hline Business - FP & 118 & 30 & $25 \%$ & 1.397 & \multirow{2}{*}{ No } & \multirow{2}{*}{ No } \\
\hline Business - NFP & 60 & 9 & $15 \%$ & & & \\
\hline Student-Not HCMT & 108 & 10 & $9 \%$ & \multirow{2}{*}{0.941} & & \\
\hline Student-HCMT & 37 & 1 & $3 \%$ & & &
\end{tabular}

Overall, $85 \%$ of the respondents consider NFP's to be businesses. The authors conclude the is a strong indicator that NFP's are considered to be "real" businesses

College textbooks define a business as "a legally recognized organization designed to provide goods and/or services to consumers." This definition excludes the requirement that businesses are formed to earn a profit. [1] However other business textbooks disclosed definitions that included a profit motive. In addition, in some books NFP's were specifically identified as organizations that were not businesses because their fundamental purpose was not to earn a profit.

Regardless of the definition of a business, most NFP organizations, like all other businesses, have all the other needs and responsibilities of FP businesses. These include:

1) The skills to manage the organization effectively

2) The ability to market, provide and distribute their product or services

3) The ability to finance the capital needs of the organization

4) The responsibility to abide by the laws, regulations and ethical standards that apply to their organization.[1]

\section{Not-for-profit organizations do not pay taxes.}

Overall, $45 \%$ of the respondents believe that NFP's do not pay taxes. There was no significant difference in this perception between business professionals (40\%) and students (50\%). Within the business professional survey, there were no significant differences in responses between FP's and NFP's. However, within the student 
survey, the HCMT had a significantly higher awareness of the tax-exempt status of NFP's $-81 \%$ for HCMT students versus $39 \%$ for all other business students. Table 5 presents the tabulation of the responses and the z-Test for this question.

Table 5

\begin{tabular}{|l|r|r|r|c|c|c|}
\hline \multicolumn{1}{|c|}{ Respondent } & $\mathrm{N}=$ & True & Percent & z-value & at 95\% & at 90\% \\
\hline Professional-Total & 178 & 72 & $40 \%$ & \multirow{2}{*}{1.544} & \multirow{2}{*}{ No } & \multirow{2}{*}{ No } \\
\hline Student-Total & 145 & 72 & $50 \%$ & & \multirow{2}{*}{ No } & \multirow{2}{*}{ No } \\
\hline Business - FP & 118 & 49 & $42 \%$ & \multirow{2}{*}{0.250} & & \multirow{2}{*}{ Yes } \\
Business - NFP & 60 & 23 & $38 \%$ & & \multirow{2}{*}{ Yes } & \\
\hline Student-Not HCMT & 108 & 42 & $39 \%$ & \multirow{2}{*}{4.230} & & \\
\cline { 1 - 4 } Student-HCMT & 37 & 30 & $81 \%$ & & & \\
\cline { 1 - 3 } & 323 & 144 & $45 \%$ & & &
\end{tabular}

Approximately $1 / 2$ of those surveyed were unaware of the tax-exempt status of NFP's. However, in retrospect, this question needed to be worded differently. NFP's generally do not pay income taxes; however, in some states (and SC is one of them), NFP's may be required to collect and remit sales taxes.

The law on this subject is seemingly clear, however many individuals do not understand the tax implications of being a not for profit. A NFP on its face is not tax exempt. NFP corporations do pay taxes, unless they take the extra step to become tax exempt. A corporation can be NFP and not be designated tax exempt. In order to be tax exempt, a NFP must file with the Internal Revenue Service an application to be tax exempt based on their status. Some NFP's qualify for tax exempt status; some do not, depending on what type of business the NFP is engaged in. For example, a hospital foundation is typically organized as a NFP corporation that gains tax exempt status under IRS Section 509(a) (3), a supporting organization. By contrast, many credit counseling corporations are organized through the Secretary of State as NFP corporations, however these entities are not designated tax exempt under the Internal Revenue Code because they do not meet the requirements to become tax exempt under either IRC Section 501, 503 or 509. [10]

Even if designated tax-exempt, a NFP still files a federal tax return, Form 990. Some states also require a tax return, but not all of them. States that do not require a tax return may still require that financial information be provided to the government agency that oversees charities.

NFP's may owe unrelated business income taxes if they have incurred unrelated business income (UBI). The IRS established a three prong test to determine UBI. An activity is considered unrelated business and subject to unrelated business income tax if it meets three requirements: 1) It is a trade or business, that 2) It is regularly carried on, and 3) the business is not substantially related to furthering the exempt purpose of the organization. [11] The IRS taxes UBI at the same rates trust income is taxed, meaning UBI will be taxed at the highest possible rates after UBI reaches $\$ 10,700$.

\section{Not-for-profit organizations cannot make a profit.}

Overall, $23 \%$ of the respondents believe that NFP's cannot make a profit. There was no significant difference in this perception between business professionals $(21 \%)$ and students $(25 \%)$. With each survey there was a significant difference of perceptions for the business professionals working in FP's versus NFP's and for students in HCMT and those not. Professionals working in NFP's and HCMT students had higher awareness that NFP's can make a profit. Table 6 presents the tabulation of the responses and the z-Test for this question. 
Table 6

\begin{tabular}{|l|r|r|r|c|c|c|}
\hline \multicolumn{1}{|c|}{ Respondent } & N= & True & Percent & z-value & at 95\% & at 90\% \\
\hline Professional-Total & 178 & 38 & $21 \%$ & \multirow{2}{*}{0.715} & \multirow{2}{*}{ No } & \multirow{2}{*}{ No } \\
\hline Student-Total & 146 & 37 & $25 \%$ & & & \multirow{2}{*}{ No } \\
\hline Business - FP & 118 & 30 & $25 \%$ & \multirow{2}{*}{1.667} & Yes \\
Business - NFP & 60 & 8 & $13 \%$ & & \multirow{2}{*}{ No } & Yes \\
\hline Student-Not HCMT & 109 & 32 & $29 \%$ & \multirow{2}{*}{1.696} & & \\
\hline Student-HCMT & 37 & 5 & $14 \%$ & & & \\
\hline All Surveyed & 324 & 75 & $23 \%$ & &
\end{tabular}

A significant number of business professionals in the FP's (25\%) and non-HCMT business students (29\%) believe NFP's cannot make a profit.

Although NFP's do not have the fundamental purpose of earning a profit, their ability to maintain and grow their organization requires that they operate profitably and retain those profits within the organization. However, terms such as "profit", "net income" and "retained earnings" are generally not used with NFP's. Instead NFP financial reports utilize terms such as "Net Assets" rather than "Retained Earnings" and "Change in Net Assets" rather than "Net Income" or "Net Profit". The basis for utilization of these terms can be found in Concept Statement No. 4 of the Financial Accounting Standards Board (FASB), "Objectives of Financial Reporting by Nonbusiness Organizations".

The FASB believes that financial accounting and reporting for both For Profit and NFP entities should focus on the following:

1) The users of the information and the types of decisions they make.

2) The information needed by users to assist them in making decisions.

3) The information that financial reporting can provide to satisfy the information needs.

However, the FASB also recognizes that the users of NFP financial reports have different objectives from users of For Profit financial reports. Financial reporting for NFP's should be useful to resource providers and other users to assist in making decisions regarding:

1) The allocation of the organization resources

2) The adequacy of the services provided

3) The ability to continue to provide services

4) Management performance with respect to their responsibilities

Financial reporting should also include information concerning:

1) The organization's economic resources, obligations and net resources

2) The performance of an organization during a reporting period[2]

Therefore the terms "Net Assets" and "Change in Net Assets" are more descriptive of the information required by users of NFP financial statements. Regardless of the nomenclature, NFP's must operate profitably to protect their operations from changing economic conditions and to insure their future viability.

\section{Not-for-profit organizations compensate managers less than for-profit businesses.}

Overall, $33 \%$ of the respondents believe that NFP's compensate managers less than FP's. There was no significant difference in this perception between business professionals (34\%) and students (33\%). With each survey there were significant differences of perceptions for the business professionals working in FP's versus NFP's and for students in HCMT and those not. Table 7 presents the tabulation of the responses and the z-Test for this question. 
Table 7

\begin{tabular}{|c|c|c|c|c|c|c|}
\hline Respondent & $\mathrm{N}=$ & True & Percent & z-value & at $95 \%$ & at $90 \%$ \\
\hline Professional-Total & 178 & 60 & $34 \%$ & \multirow{2}{*}{-0.004} & \multirow{2}{*}{ No } & \multirow{2}{*}{ No } \\
\hline Student-Total & 142 & 47 & $33 \%$ & & & \\
\hline Business - FP & 118 & 33 & $28 \%$ & \multirow{2}{*}{2.104} & \multirow{2}{*}{ Yes } & \multirow{2}{*}{ Yes } \\
\hline Business - NFP & 60 & 27 & $45 \%$ & & & \\
\hline Student-Not HCMT & 106 & 40 & $38 \%$ & \multirow{2}{*}{1.881} & \multirow{2}{*}{ No } & \multirow{2}{*}{ Yes } \\
\hline Student-HCMT & 36 & 7 & $19 \%$ & & & \\
\hline All Surveyed & 320 & 107 & $33 \%$ & & & \\
\hline
\end{tabular}

In a study by Lester M. Salamon and S. Wojciech Sokolowski, the authors noted that nonprofit wages are generally lower than wages in For Profit companies and government jobs. This generalization however, does not hold true in industries where NFP's and FP's compete. In such an environment, NFP wages are generally equal to or significantly ahead of FP organizations. For example, in the healthcare sector, average weekly wages are virtually the same for both NFP's and FP's. In the education, social services and day care sectors, nonprofit wages generally exceed wages paid by FP's. [7]

Bruce R. Ellig, in his book The Complete Guide to Executive Compensation discusses the differences between NFP and FP manager compensation. He notes that unlike its FP cousin, profit maximization is not the main goal of a NFP. Additionally, since a NFP may have negative tax consequences if it has too much income, paying reasonable compensation to officers and managers will aid in income reduction in a NFP. Compensation is a tax deductible expense that will reduce income and therefore offset any profit for a NFP company. Therefore, as long as the NFP organization enjoys a time of prosperity, most top officers and managers are compensated at a level up to or higher than the FP counterparts. However, the total compensation package for FP entities often includes some form of incentive compensation. Because NFP companies do not issue stock, stock incentives are not available to employees of a NFP companies. Thus, total compensation for officers and managers of a NFP versus a FP is difficult to measure. [12]

\section{Not-for-profit organizations cannot do joint ventures with for-profits businesses.}

Overall, $21 \%$ of the respondents believe that NFP's cannot do joint ventures with FP's. There was a significant difference in this perception between business professionals (15\%) and students (28\%). Within the business professional survey, there was no significant difference in responses between FP's and NFP's. However, within the student survey, the HCMT had a significantly lower awareness of this issue; $41 \%$ believed NFP's and FP's cannot do join ventures together. Table 8 presents the tabulation of the responses and the z-Test for this question.

Table 8

\begin{tabular}{|c|c|c|c|c|c|c|}
\hline Respondent & $\mathrm{N}=$ & True & Percent & z-value & at $95 \%$ & at $90 \%$ \\
\hline Professional-Total & 176 & 27 & $15 \%$ & \multirow{2}{*}{2.686} & \multirow{2}{*}{ Yes } & \multirow{2}{*}{ Yes } \\
\hline Student-Total & 145 & 41 & $28 \%$ & & & \\
\hline Business - FP & 116 & 20 & $17 \%$ & \multirow{2}{*}{0.751} & \multirow{2}{*}{ No } & \multirow{2}{*}{ No } \\
\hline Business - NFP & 60 & 7 & $12 \%$ & & & \\
\hline Student-Not HCMT & 108 & 26 & $24 \%$ & \multirow{2}{*}{1.708} & \multirow{2}{*}{ No } & \multirow{2}{*}{ Yes } \\
\hline Student-HCMT & 37 & 15 & $41 \%$ & & & \\
\hline All Surveyed & 321 & 68 & $21 \%$ & & & \\
\hline
\end{tabular}

This is perhaps a more esoteric issue and one not covered with much emphasis with the students in the business program. 
O'Kelley and Thompson in their book Corporations and Other Business Associations list factors common to a joint venture including: a joint right of control, the right to share profits and a duty to share losses, as well as a joint interest in the subject matter or venture that is the basis for the joint venture. Joint ventures are used by companies in today's business in situations where two companies would like to pursue items such as research, marketing strategies or new products together, but do not want to create a full fledged partnership. [13]

A NFP company can engage in a joint venture with a for-profit entity. The corporate code of most states specifically grants to NFP companies the ability to enter into a joint venture. Thus, no legal limitation on such a joint venture exists. The limitation is a tax limitation. A NFP entity that enjoys tax-exempt status must ascertain that its joint partner and the joint venture do not violate the NFP's exempt activity or the tax-exempt company may risk losing its tax exempt status.

In 2004, the Internal Revenue Service issued Revenue Ruling 2004-51 as guidance on the pitfalls of a NFP company that benefits from tax exempt status entering into a joint venture with a FP company. In this revenue ruling, the IRS points out that the FP Company's actions are attributed to the NFP's business activities when determining whether the NFP stays within its tax-exempt purpose. Therefore, although it is legal for a NFP and a FP company to enter into a joint venture, while in this joint venture relationship, the NFP must ensure that the operations of the joint venture do not serve a private interest rather than the charitable interest of the NFP. [14] Indeed, the tax court stated in St. David's Health Care System v. United States that a NFP must have the "capacity to ensure that the partnership's operations further charitable purposes." If control is not obtained and maintained by the NFP, then according to the Internal Revenue Service, "the non-profit should lose its tax-exempt status if it cedes control to the for-profit entity." Id. at 239. [15]

\section{Not-for-profit organizations are not permitted to compete with for-profits businesses.}

Overall, $23 \%$ of the respondents believe that NFP's are not permitted to compete with for-profits businesses. There was no significant difference in this perception between business professionals (19\%) and students $(28 \%)$ and no significant difference within each survey group. Table 9 presents the tabulation of the responses and the z-Test for this question.

Table 9

\begin{tabular}{|l|r|r|r|c|c|c|}
\hline \multicolumn{1}{|c|}{ Respondent } & $\mathrm{N}=$ & True & Percent & z-value & at 95\% & at 90\% \\
\hline Professional-Total & 175 & 34 & $19 \%$ & \multirow{2}{*}{1.590} & \multirow{2}{*}{ No } & \multirow{2}{*}{ No } \\
\hline Student-Total & 145 & 40 & $28 \%$ & & \multirow{2}{*}{ No } & \multirow{2}{*}{ No } \\
\hline Business - FP & 116 & 26 & $22 \%$ & \multirow{2}{*}{1.197} & \multirow{2}{*}{ No } & \multirow{2}{*}{ No } \\
\hline Business - NFP & 59 & 8 & $14 \%$ & & & \\
\hline Student-Not HCMT & 108 & 32 & $30 \%$ & \multirow{2}{*}{0.728} & & \\
\cline { 1 - 4 } Student-HCMT & 37 & 8 & $22 \%$ & & &
\end{tabular}

NFP's can and do compete with FP businesses. According to an analysis of 2006 employment data, there are 24 industries in the North American Industry Classification System (NAICS) that each employs more than 100,000 NFP employees. Each of these industry categories also has employees within the FP sector. The total NFP employees in the 24 categories were 9.7 million versus 11.4 million employees in the FP group. Therefore there appears to be substantial competition between NFP's and FP's. The healthcare sector, including hospitals, nursing homes, physicians offices, outpatient care centers and mental health organizations, account for almost half of the NFP employees and over $42 \%$ of the FP employees in these industries. [9] The FP portion of the healthcare sector has grown significantly since the advent of Medicare and Medicaid in the 1960s, and the growth was further fueled by the development of managed care in the 1990s.[3] As of 2006, NFP hospital employees still far outnumber the FP hospital employees. However approximately $74 \%$ of employees in the Nursing Home area were employed by FP entities. [9] 


\section{Not-for-profit organizations are expected to only break-even.}

Overall, $26 \%$ of the respondents believe that NFP's are expected to only break-even. There was no significant difference in this perception between business professionals (29\%) and students (23\%) and no significant difference within each survey group. Table 10 presents the tabulation of the responses and the z-Test for this question.

Table 10

\begin{tabular}{|c|c|c|c|c|c|c|}
\hline Respondent & $\mathrm{N}=$ & True & Percent & z-value & at $95 \%$ & at $90 \%$ \\
\hline Professional-Total & 178 & 52 & $29 \%$ & \multirow{2}{*}{1.182} & \multirow{2}{*}{ No } & \multirow{2}{*}{ No } \\
\hline Student-Total & 145 & 33 & $23 \%$ & & & \\
\hline Business - FP & 118 & 38 & $32 \%$ & \multirow{2}{*}{1.056} & \multirow{2}{*}{ No } & \multirow{2}{*}{ No } \\
\hline Business - NFP & 60 & 14 & $23 \%$ & & & \\
\hline Student-Not HCMT & 108 & 27 & $25 \%$ & \multirow{2}{*}{0.872} & \multirow{2}{*}{ No } & \multirow{2}{*}{ No } \\
\hline Student-HCMT & 37 & 6 & $16 \%$ & & & \\
\hline All Surveyed & 323 & 85 & $26 \%$ & & & \\
\hline
\end{tabular}

This question is similar to question 3, "Not-for-profit organizations cannot make a profit." However, this question focuses on public expectations versus legal limitations.

While this perception sounds somewhat logical on the surface, the actual operation of an organization in a breakeven mode defies practicality. If a NFP could not make any profit, then NFP's that operate profitably (i.e. have a positive change in net assets) would be required to "give away" that increase. The assets would not be available for future growth or for economic changes that could negatively impact the organization. NFP's with a negative change in net assets would need to be able to borrow on relatively short notice and in a breakeven environment repayment of debt would not be possible.

\section{Not-for-profit organizations and for-profit businesses can sell stock to raise capital.}

Overall, $34.4 \%$ of the respondents believe that NFP's can sell stock to raise capital. There was no significant difference in this perception between business professionals (33\%) and students (36\%). With each survey there were significant differences of perceptions for the business professionals working in FP's versus NFP's and for students in HCMT and those not. Business professional working in NFP's and HCMT students had much higher awareness that NFP's cannot sell stock. Table 11 presents the tabulation of the responses and the z-Test for this question.

Table 11

\begin{tabular}{|c|c|c|c|c|c|c|}
\hline Respondent & $\mathrm{N}=$ & True & Percent & z-value & at $95 \%$ & at $90 \%$ \\
\hline Professional-Total & 171 & 56 & $33 \%$ & \multirow{2}{*}{0.507} & \multirow{2}{*}{ No } & \multirow{2}{*}{ No } \\
\hline Student-Total & 144 & 52 & $36 \%$ & & & \\
\hline Business - FP & 112 & 43 & $38 \%$ & \multirow{2}{*}{1.887} & \multirow{2}{*}{ No } & \multirow{2}{*}{ Yes } \\
\hline Business - NFP & 59 & 13 & $22 \%$ & & & \\
\hline Student-Not HCMT & 107 & 44 & $41 \%$ & \multirow{2}{*}{1.930} & \multirow{2}{*}{ No } & \multirow{2}{*}{ Yes } \\
\hline Student-HCMT & 37 & 8 & $22 \%$ & & & \\
\hline All Surveyed & 315 & 108 & $34 \%$ & & & \\
\hline
\end{tabular}

The ability to raise capital by selling a portion of the company represented by a share of stock is a well recognized benefit of the corporate form of operation for a For Profit business. As an owner, the stockholder has an interest in the company's earnings and in any assets distributed upon liquidation of the entity. The issuance of stock also permits ownership interests to be easily transferred after issuance. 
Not-for-profit organizations are structured somewhat differently than their for-profit cousins. As noted above one of the major distinguishing characteristics of NFP's is the absence of defined ownership interests that can be sold or transferred or that allows for a share of the residual assets of the organization. [2] Therefore the ability to sell stock and pay dividends has no meaning within the NFP realm. Since NFP organizations are not organized with stock, the organizations cannot sell stock to raise capital and do not have shareholders. Certain types of NFP's have members that are akin to shareholders, however, members have no "ownership" in the corporation and transferability of the member's interest is very limited. Typically, only a mutual benefit corporation (such as a booster club or fraternal organization) will have members and generally state statutes have no requirement that NFP's have members.

\section{Not-for-profit organizations, like for-profit businesses, can pay dividends to its owners.}

Overall, 26\% of the respondents believe that NFP's can pay dividends to its owners. There was no significant difference in this perception between business professionals (24\%) and students (28\%) and no significant difference within each survey group. Table 12 presents the tabulation of the responses and the $\mathrm{z}$-Test for this question.

Table 12

\begin{tabular}{|c|c|c|c|c|c|c|}
\hline Respondent & $\mathrm{N}=$ & True & Percent & z-value & at $95 \%$ & at $90 \%$ \\
\hline Professional-Total & 176 & 42 & $24 \%$ & \multirow{2}{*}{0.745} & \multirow{2}{*}{ No } & \multirow{2}{*}{ No } \\
\hline Student-Total & 142 & 40 & $28 \%$ & & & \\
\hline Business - FP & 116 & 30 & $26 \%$ & \multirow{2}{*}{0.678} & \multirow{2}{*}{ No } & \multirow{2}{*}{ No } \\
\hline Business - NFP & 60 & 12 & $20 \%$ & & & \\
\hline Student-Not HCMT & 106 & 33 & $31 \%$ & \multirow{2}{*}{1.133} & \multirow{2}{*}{ No } & \multirow{2}{*}{ No } \\
\hline Student-HCMT & 36 & 7 & $19 \%$ & & & \\
\hline All Surveyed & 318 & 82 & $26 \%$ & & & \\
\hline
\end{tabular}

As previously noted, NFP organizations do not have shareholders and do not issue stock. Since the structure of NFP organizations is not that of equity ownership, no dividends can be paid to the owners. The laws regulating NFP's specifically restrict distributions to members, except in two specific situations which include the repurchasing of membership interests from members and distributions upon dissolution of the NFP organization. Other than these specific situations, most states do not allow any other distributions, including dividend distributions.

10. Not-for-profit organizations and for-profit businesses can accept donations and the amount is taxdeductable by the donor to the extent the donation exceeds the value of goods or services received.

Overall, 56\% of the respondents believe that NFP's and FP's can accept tax-deductable donations. There was a significant difference in this perception between business professionals (38\%) and students (78\%). Within the business professional survey, there was no significant difference in responses between FP's and NFP's. However, within the student survey, the HCMT had a significantly higher awareness. $67 \%$ believed both can accept taxdeductible donations FP's cannot do joint ventures together; 82\% of non-HCMT students held the same belief. Table 13 presents the tabulation of the responses and the $\mathrm{z}$-Test for this question.

Table 13

\begin{tabular}{|c|c|c|c|c|c|c|}
\hline Respondent & $\mathrm{N}=$ & True & Percent & z-value & at $95 \%$ & at $90 \%$ \\
\hline Professional-Total & 175 & 66 & $38 \%$ & \multirow{2}{*}{7.101} & \multirow{2}{*}{ Yes } & \multirow{2}{*}{ Yes } \\
\hline Student-Total & 145 & 113 & $78 \%$ & & & \\
\hline Business - FP & 117 & 44 & $38 \%$ & \multirow{2}{*}{0.125} & \multirow{2}{*}{ No } & \multirow{2}{*}{ No } \\
\hline Business - NFP & 58 & 22 & $38 \%$ & & & \\
\hline Student-Not HCMT & 109 & 89 & $82 \%$ & \multirow{2}{*}{2.647} & \multirow{2}{*}{ No } & \multirow{2}{*}{ Yes } \\
\hline Student-HCMT & 36 & 24 & $67 \%$ & & & \\
\hline All Surveyed & 320 & 179 & $56 \%$ & & & \\
\hline
\end{tabular}


The difference in opinions between business professionals and business students on this question can be partially explained by life experiences. It is unlikely that many of the students have itemized their income tax returns; additionally, except for those studying accounting, most of the students have not taken a course in taxation.

The Internal Revenue Code gives clear guidance on the deductibility of money or items donated to a taxexempt organization. The code states that contributions to "qualified organizations" are tax deductible to the extent the fair market value exceeds any amount received by the donor from the qualified organization. The Internal Revenue Code describes qualified organization as 1) a state or the United States if the contribution is for a public purpose; 2) a corporation, trust, community chest, fund or foundation organized and operated solely for religious, charitable, scientific, literary or educations purposes or to foster amateur sports or to prevent cruelty to children or animals; 3 ) a post or organization for war veterans; or 4) a cemetery company owned and operated exclusively for the benefit of its members. The crux of determining whether contributions to an entity are deductible is Section 170 (c)(2)(d) which explains that any of the organizations described above must not be disqualified for tax exemption under Section 501(c)(3). [16] This qualification means that again a corporation that simply holds the designation not-for-profit may not accept donations that become tax deductible to the donor; instead, corporations must take the extra step to apply for tax-exempt status under Section 501(c)(3) of the Internal Revenue Code. Once that status has been obtained, the fair market value of items donated will become tax-deductible to the donor.

\section{CONCLUSIONS}

Not for profit organizations are a growing segment of the global economy. NFP's conduct business, employ individuals, and compete in the marketplace. Still, misconceptions exist about the operations of NFP's so the authors conducted a survey to determine the level and extent of these supposed misconceptions. The survey answers proved these supposed misconceptions were, in fact, true. The answers discussed in this paper were close to what the authors predicted, with an average of $27 \%$ of individuals not knowing the correct response to each question. This survey was conducted in Greenwood, South Carolina, a county of approximately 68,500 in western South Carolina. The authors would like revised the survey and conduct further study on a broader region, to determine if these misconceptions are true across a broader field.

\section{AUTHOR INFORMATION}

Sam Tolbert holds the position of Associate Professor of Health Care Management at Lander University in Greenwood, SC. Prior to becoming a full-time academic in 2000, he spent 25 years as a health care executive working in both for-profit and not-for-profit organizations. Sam holds a masters degree from Georgia Institute of Technology, is a Fellow in the American College of Healthcare Executives, and has published nine journal articles.

Gail Moore is a CPA and attorney who holds the position of Assistant Professor of Business Law and Taxation at Lander University in Greenwood, SC. She holds a Bachelor of Science in Business Administration, Accounting, and a Juris Doctorate Degree from the University of South Carolina. Prior to teaching full time, Gail practiced law and accounting for 12 years in private practice.

Carol Wood is a CPA with more than 25 years experience in accounting and financial management. After receiving her Master of Accountancy degree from the University of South Carolina in 1979, she spent ten years with an international public accounting firm. She then moved into private industry and served as Chief Financial Officer for companies headquartered in the southeast. Her background includes accounting and tax consulting, as well as experience in mergers, acquisitions and dispositions of businesses and business segments. In 2005 she entered academia and is an Assistant Professor of Accounting at Lander University in Greenwood, SC.

\section{REFERENCES}

1. Ferrell, O.C.; Hirt, Geoffrey, and Ferrell, Linda. Business: A Changing World. New York: McGraw- Hill Irwin, 2008, 7.

2. Financial Accounting Standards Board. "Statement of Financial Accounting Concepts No. 4, Objectives of Financial Reporting by Nonbusiness Organizations." 1980, December, 
3. Henderson, James W. Health Economics \& Policy, $2^{\text {nd }}$ Edition. Cincinnati, Ohio: South-Western Thomson Learning, 2002, 269-298.

4. Ingram, Sarah Hall. "Nonprofit Governance - The View from the IRS.” Remarks of Sarah Hall Ingram, Commissioner, Tax Exempt and Government Entities, Internal Revenue Service, Before the Georgetown University Law Center Continuing Legal Education, June 23, 2009.

5. Internal Revenue Service. “Applying for 501(c) (3) Tax-Exempt Status.” IRS Publication 4220, (Rev. 0607).

6. Ives, Martin; Johnson, Laurence; Razek, Joseph R.; and Hosch, Gordon A. Introduction to Governmental and Not-for-Profit Accounting, $6^{\text {th }}$ Edition. New Jersey: Pearson Prentice Hall, 2009, 452-501.

7. Salaman, Lester M.; and Sokolowski, S. Wojciech. Monthly Labor Review, 2005, September, 19-26.

8. Warren, Zack. "Occupational Employment in the Not-For-Profit Sector." Monthly Labor Review, 2008, November, 11-43.

9. Internal Revenue Code, Title 26, Section A, Chapter 1, Subchapter F, Part III, Section 503.

10. Internal Revenue Code, Title 26, Section A, Chapter 1, Subchapter F, Part III, Section 513.

11. Ellig, Bruce R. The Complete Guide to Executive Compensation, McGraw-Hill Companies, 2007, 30-32.

12. O'Kelley, Charles R. Jr.; Thompson, Robert B. Corporations and Other Business Associations, Little, Brown \& Co, 1992, 61.

13. Revenue Ruling 2004-51, I.R.B. 2004-22, June 1, 2004.

14. St. David's Health Care System v. United States, 349 F.3d 232, 236-237 (5th Cir. 2003).

15. Internal Revenue Code, Title 26, Section A, Chapter 1, Subchapter B, Part IV, Section 170. 


\section{NOTES}

